\title{
ЛІНГВІСТИКА: НАУКА - ДИДАКТИКА - ФІЛОСОФІЯ МОВИ - МЕТОДОЛОГІЯ (ДИСКУРСИВНО-КОМУНІКАТИВНИЙ АСПЕКТ ПРОБЛЕМИ)
}

\author{
Оксана ПРОСЯНИК
}

\author{
доктор філологічних наук, доцент \\ Харківський національний економічний університет імені Семена Кузнеця (Україна) \\ e-mail: oxppros@gmail.com \\ UDC: $81-13$ \\ https://orcid.org/0000-0001-6704-5391
}

DOI 10.25128/2304-1222.20.50.02

\begin{abstract}
The article touched upon the problem of delimitation of the concepts of linguistics as a science, linguodidactics, philosophy of the language and linguistic methodology. The purpose of the article is to make an attempt to determine the boundaries between the linguistic science itself, the practice of using linguistic knowledge, in the academic field in particular, and the philosophy of the language, and to determine the place of linguistic methodology in the system of these differences. The emphasis is made on the pragmafunctional specificity of these forms of intellectual activity. In addition to basic pragmatics, the difference between scientific and utilitarian-practical information itself appears when they are analyzed in the light of the structure of socialization of information and the discursive strategy used in the process of their creation. Outlining the specifics of the scientific text and scientific information, the author draws attention to the difference between scientific information and philosophical-worldview one. There is an emphasis on the importance of methodology for those sciences, which object is not directly empirically given, to which linguistics belongs. The specifics of scientific text and scientific information of various types is outlined on the discursive and communicative grounds.
\end{abstract}

Keywords: linguistics, science, philosophy of language, methodology, information, discourse, communication

Artykuł dotyczy problemu rozgraniczenia pojęć językoznawstwa jako nauki, dydaktyki językowej, filozofii języka i metodologii lingwistycznej. Celem artykułu jest próba ustalenia granic między właściwą nauką językoznawczą, praktyką korzystania z wiedzy językowej, w szczególności w dziedzinie akademickiej, a filozofią języka oraz określenie miejsca metodologii lingwistycznej w systemie tych różnic. Nacisk kładziony jest na pragmatyczno-funkcjonalną specyfikę tych form aktywności intelektualnej. Oprócz podstawowej pragmatyki różnice między informacjami naukowymi i utylitarnymi ujawniane są w trakcie analizy struktury socjalizacji informacji $i$ wykorzystywanych $w$ procesie jej kreowania strategii dyskursywnych. Przedstawiając specyfikę tekstu naukowego i informacji naukowej, autor zwraca uwagę także na różnicę między informacjami naukowymi a poglądami światopoglądowo-metodologicznymi. Podkreślone zostało znaczenie metodologii dla nauk, których przedmiotem nie są bezpośrednie dane empiryczne, do których należy również lingwistyka. Dyskursywne i komunikatywne podstawy przedstawiają specyfikę tekstu naukowego i informacji naukowych różnego typu.

Słowa kluczowe: językoznawstwo, nauka, filozofia języka, metodologia, informacja, dyskurs, komunikacja

У статті порушено проблему делімітації понять лінгвістика як наука, лінгводидактика, філософія мови та лінгвістична методологія. Метою статті є здійснити спробу визначення меж між власне лінгвістичною наукою, практикою використання лінгвістичних знань, зокрема в академічній сфері, та філософією мови, а також визначити місце лінгвістичної методології у системі цих розрізнень. Акцент робиться на прагмафункціональній специфіці цих форм інтелектуальної діяльності. Крім базової прагматики, відмінність між власне науковою та утилітарно-практичною інформацією виникає тоді, коли їх аналіз здійснюється 3 огляду на структуру соціалізації інформації та використовуваної у процесі їх створення дискурсивної стратегії. Окреслюючи специфіку наукового тексту й наукової інформації, авторка звертає увагу на відмінність наукової інформації від філософсько-світоглядної. Наголошується на важливості методології для тих наук, об'єкт яких не $є$ 
безпосередньо емпірично даним, до яких належить мовознавство. На дискурсивно-комунікативних підставах окреслено специфіку наукового тексту й наукової інформації різного типу.

Ключові слова: лінгвістика, наука, філософія мови, методологія, інформація, дискурс, комунікація

У період постмодерністичних пошуків на пограниччях наук, науки й філософії, науки й паранаукових пізнавальних систем визначилась тенденція до затирання меж між власне науковим та ненауковим лінгвістичним пізнанням. Ми не прагнемо вирішувати це питання, вказуючи, котра 3 форм пізнання $\epsilon$ «справжнім» пізнанням, а котра ні, оскільки 3 перспективи антропоцентризму кожна з його форм має право на існування, ані не маємо на меті аксіологізувати цю проблему, визначаючи «кращі» і «гірші» форми пізнання, оскільки 3 прагматичної точки зору кожна 3 цих форм служить іншим цілям і є виправданою. Метою пропонованої статті є визначення меж між лінгвістичною наукою, практикою використання лінгвістичних знань та філософією мови, а також визначення місця лінгвістичної методології у системі цих розрізнень.

До класичних дефініцій науки можна віднести визначення такого типу: «Наука - це процес творчої діяльності по отриманню нового знання, і результат цієї діяльності у вигляді цілісної системи знань, сформульованих на основі певних принципів (...) Наука - сфера людської діяльності, функцією якої є вироблення і систематизація об'єктивних знань про дійсність; одна з форм суспільної свідомості (...) Поняття "наука" охоплює як діяльність, спрямовану на отримання нового знання, так і результат цієї діяльності - суму здобутих на певний час знань, сукупність яких створює наукову картину світу» [Бірта, Бургу 2014]. Можна в цілому погодитись $з$ такою дефініцією, якщо врахувати декілька суттєвих моментів. По-перше, те, що як «творча діяльність по отриманню нового знання», так і «цілісна система знань», що постає у результаті такої діяльності, це суто антропні функції, притаманні не суспільству чи абстрактному колективному науковому розуму, а конкретній особі вченого, який реалізує таку діяльність і накопичує у пам'яті таку систему знань. По-друге, варто застерегти від абсолютизації поняття «об’єктивні знання», розуміючи під ним раціонально верифіковані знання, по можливості позбавлені упереджень та емоційних оцінок, але в жодному разі не знання, які відповідають дійсності чи реальному стану речей, оскільки у людини немає можливості верифікувати такі знання чи довести їх абсолютну істинність. Потретє, поняття «суспільної свідомості» також варто інтерпретувати як результат комунікативної практики і не намагатися його гіпостазувати до рівня метафізичної сутності. Ключовими, на нашу думку, у наведеній дефініції є поняття діяльності (яке виражає онтологічну суть науки), наукової картини світу (у якій закладено цільову прагматику такої діяльності) та принципів (на яких каузально базується така діяльність, тобто методології наукової діяльності). 
На жаль, у дефініції експліцитно не прописаний ще один важливий момент, без якого важко зрозуміти, яким чином виникає і функціонує наука саме як суспільна свідомість. 3 позицій філософської метафізики вистачило б надати суспільній свідомості рис об'єктивно існуючого колективного розуму (наприклад, духу народу чи ноосфери), і тоді можна стверджувати, що знання, отримані конкретним ученим, не залишаються у його свідомості, а стають надбанням людства i переходять у загальну «скарбницю знань». Проте таке розуміння суперечить антропоцентричним переконанням про неможливість існування метафізичних інформаційних систем. Залишається одне - передбачити процес соціалізації індивідуально витвореного наукового знання через дискурсивні комунікативні процеси.

Дискурсивність наукового знання має декілька вимірів. 3 одного боку, неоприлюднені належним чином знання окремого вченого можуть залишитися його особистими знаннями $\mathrm{i}$ зникнути разом з його смертю. 3 іншого - такі знання не могли б виникнути, якби дослідник не опирався на знання своїх попередників, не намагався їх верифікувати чи фальсифікувати, нарешті, не намагався узгодити свої дослідження з дослідженнями інших. Але це ще не все. У процесі такої соціалізації і на етапі підготовки до дослідження (коли вчений інтерпретує наукові тексти своїх попередників), так і на етапі популяризації результатів свого дослідження (коли інші дослідники інтерпретують його тексти) можуть виникати численні надінтерпретації, редукції і трансформації, в результаті яких виникає інформація, що є часом досить відмінною від початкової. А оскільки т.зв. обіг наукової інформації не спроваджується до простої схеми «адресант - адресат», те, що ми звикли називати науковим знанням, нерідко є похідною величезної кількості компромісів і мисленнєвих спрощень. Навіть якщо ми не звертатимемо увагу на інтерпретації і реферування наукових знань i звернемося до джерела (автора теорії чи концепції), не можна бути впевненим, що: а) ми самі не здійснили надінтерпретації і б) сам автор мав на увазі не те, що написав (помилився, був непослідовним, не вмів висловлюватися ясно і виразно, не був впевнений у своїх поглядах, змінив свою думку відносно того, про що писав раніше і т.п.). Саме тому ми наполягаємо на принципово дискурсивному характері науки як форми суспільної свідомості.

Нас цікавить два питання: по-перше, яким критеріям має відповідати система знань і діяльність в цілому, щоб їх можна було назвати науковими, а по-друге, чим принципово відрізняється лінгвістичне наукове пізнання від ненаукового.

Розпочати аналіз цих проблем варто 3 розрізнення наукового i практичного (утилітарного) знання (інформації). Це розрізнення можна ефективно реалізувати на прагматичній основі ${ }^{1}$, адже із семантичного (тематичного) чи формального (зокрема й мовного) поглядів вербалізована в тексті наукова інформація може принципово не

\footnotetext{
${ }^{1}$ Теоретичну основу нашого аналізу специфіки наукової інформації становить насамперед праця українськопольського мовознавця й методолога О. В. Лещака [Лещак 1996; Лещак 2002; Leszczak 2013].
} 
відрізнятися від практично-утилітарної. Якщо зосередитися на мовознавчій тематиці, найкращим прикладом тут можуть служити монографії (чи наукові статті), вишівські підручники (чи мовні порадники), науково-популярні тексти та мовні експертизи (зокрема судові). Лише перші мають на меті пізнання в його соціокультурному та цивілізаційному аспектах. Підручник, науково-популярна стаття в глянцевому журналі чи експертна оцінка не мають на меті внести якусь принципово нову інформацію в соціокультурну, а тим більше в наукову картину світу. Їхнє завдання суто практичне: поширити вже створене й доведене (краще чи гірше) знання серед зацікавленої публіки (науково-популярний твір), майбутніх фахівців (дидактичний твір) або ж розв’язати конкретну практичну (правову, господарську чи соціальну) проблему за допомогою такого наукового знання. Саме ж таке знання (як персоналізована чи вже соціалізована інформація) може виникнути лише в межах науковопізнавальної діяльності й науковому дискурсі.

У чому ще, крім базової прагматики, може полягати відмінність між власне науковою та утилітарно-практичною інформацією? Як вже було сказано вище, семантика і форма таких текстів можуть бути дуже подібними. I науковий, i дидактичний текст (особливо академічний) можуть бути однаковою мірою раціонально-логічними, насиченими науковими поняттями й термінологією. Проте суттєва відмінність між ними виникає тоді, коли ми проаналізуємо їх із погляду структури соціалізації інформації та використовуваної у процесі їх створення дискурсивної стратегії. Утилітарно-практичний текст, по-перше, має бути комунікативним (спрямованим на його зрозумілість для реципієнта), а тому, по-друге, бути висококонвенціональним (спиратися на загальноприйняті в певній сфері діяльності лінгвосеміотичні засади). На відміну від нього науковий текст, що $\epsilon$ продуктом індивідуальної пізнавальної творчості, має бути передусім експресивним (експресивність розуміємо за празькою школою як функцію вираження інтенції), а по-друге, бути когерентним. Обидві ці риси створюють суттєву перешкоду для сприйняття наукової інформації не лише далекою від науки людиною, але часто й науковцями, адже завданням вченого (особливо у випадку, коли він занурюється в мало досліджену галузь чи шукає нові шляхи розв’язання пізнавальної проблеми) є не задовольнити цікавість майбутнього читача $\mathrm{i}$ навіть не поінформувати своїх колег-науковців про своє відкриття, а насамперед виразити у вербально-текстовій формі свої роздуми й умовиводи. Звідси - необхідність опрацювання специфічних концептуальних і дискурсивних методик інтерпретації наукового тексту. Сказане імплікує ще один суспільно-культурний аспект принципової різниці між науковим $\mathrm{i}$ утилітарно-практичним текстами. Науковий текст завжди створений для інших науковців, причому що більш новаторський текст, то вужче коло осіб, яким він адресований. Експертський текст пишуть для того, щоб його міг сприйняти кожен фахівець цієї сфери, дидактичний текст 
зорієнтований на кожного, хто навчається на цьому освітньому рівні, а науково-популярний (зокрема й енциклопедичний) - на кожного, хто непрофесійно цікавиться певною проблемою.

Ще один момент, на який можна і необхідно звернути увагу, окреслюючи специфіку наукового тексту й наукової інформації, - це відмінність наукової інформації від філософсько-світоглядної. Нерідко наукову працю (зокрема в галузі гуманітарних чи суспільних наук, особливо теоретичну чи фундаментальну, а також інтердисциплінарну) досить важко відрізнити від філософської (особливо якщо це праця з етики, естетики, філософії суспільства, політики чи філософії мови). Утім, плинний характер людської культурно-інформаційної діяльності не означає, що наука i філософія принципово не відрізняються. Як і в попередньому випадку, відмінність полягає саме в прагматиці творення інформації та способі іiі соціалізації. У цьому випадку доречно було б звернутися до концепції польського вченого - соціокібернетика Маріана Мазура [Mazur 1981], котрий запропонував таку схему розрізнення науки, філософії і мистецтва (трьох базових галузей віртуальної сфери людського досвіду): за критерієм узагальнення й систематизації оперованою інформацією наука і філософія принципово відрізняються від мистецтва, яке завжди оперує конкретною інформацією і не намагається створити цілісної дедукційно структурованої системи картини світу, натомість за критерієм аргументації наука принципово відрізняється як від мистецтва, так і від філософії. Науковець повинен логічно та методично аргументувати положення своєї концепції чи теорії й мусить спекулятивно чи емпірично довести свої тези (отже, у його праці повинні бути як узагальнювальні твердження, так і доказові процедури). Філософ чи митець такого обов'язку не мають, тому у першого зазвичай відсутня доказова база, а у другого немає ні тверджень, ні доказів. М. Мазур виділяє відповідно три види суджень - наукові тези, в яких інформація подана як правдива чи неправдива і підтверджена доведенням ії правдивості, філософські запевнення, в яких інформація представлена як правдива без належного доведення іiї правдивості, і художні одкровення, в яких інформація представлена як така, що не має жодного стосунку до правди чи неправди, а отже як така, що не має бути підтверджена.

Окрім того, філософа на відміну від науковця цікавить не стільки знання як таке, у його співвідношенні з іншим знанням чи світом досвіду, скільки переживання моменту пізнання, а також оцінка вартості здобутого знання, надання йому аксіологічної значущості. Послуговуючись мовознавчими термінами, можна сказати, що науковця цікавить у тексті зміст (значення) і раціональний смисл, а філософа - культурно-цивілізаційна значущість смислу і його цінність для людського життя. Це накладає відбиток на філософський текст. Він рідко буває логічно структурованим, термінологічно й концептуально послідовним, майже ніколи не $є$ спеціалізованим, часто буває надто індивідуалізованим (завдяки оцінності) і майже завжди апелює до емоцій, переконань і віри реципієнта. 
Філософська інформація має захоплювати й заохочувати суб'єкт до визначення свого стосунку до світу. Наукова інформація, натомість, повинна давати в міру відсторонені знання про світ. Навіть якщо в обох випадках об'єктом рефлексії є людина як така чи як сам мислячий індивід, філософська рефлексія зосереджується на суб'єктних характеристиках інформації, а наукова - на їі об'єктних ознаках. Філософ не повинен відмежовуватися від об’єкта роздумів, не прагне, а найчастіше й не може визволитися від свого ставлення до об'єкта, вчений же, навпаки, шукає методи саме такого відмежування й визволення. Саме тому не можна не розрізняти наукові концепції і теорії та філософські концепції й доктрини.

Звісно, беручи до уваги різнорідність наук (зазвичай у слов'янських мовних культурах говорять про природничо-технічні і гуманітарно-суспільні науки, в англомовному світі - про science i arts, а у франкомовному - про science i lettres) та типологічний характер розуміння людського культурного досвіду, можна ствердити, що науки, спрямовані на пізнання світу природи, більшою мірою відрізняються від філософії, ніж науки, об'єктом яких є світ людини як такої, як особистості чи як члена суспільства, а отже й світ людських стосунків. Мовознавство, без сумніву, належить саме до таких наук, адже мови та їхня реалізація в актах мовлення - це суто інформаційні функції, які не існують поза людською психікою i поза міжлюдськими стосунками. Єдині власне матеріальні (фізичні) вияви мовної діяльності, що є об'єктами мовознавства - звуки мовлення, фактично цікавлять лінгвістів не як такі, а лише як продукти артикуляції чи акустичні подразники, фізична якість котрих має вже незначний вплив на сутність мовленнєвого акту як процедури сигнального обміну інформацією. Власне мовознавчим об'єктом є не вони, а мовні та мовленнєві значення (лексичні, граматичні, стилістичні, дискурсивні) і суміжні з ними акустико-артикуляційні функції (акустичні враження, артикуляційні моделі, фонеми тощо). Оминаючи дискусію, якою мірою природничі науки вільні від інформаційних можливостей і дій суб'єкта (досить згадати тут славнозвісну засаду Гейзенберга чи модну останнім часом антропну засаду), можна спрощено сказати, що природничо-технічні науки досліджують (прагнуть досліджувати) головним чином матеріальні об'єкти, натомість суспільно-гуманітарні (зокрема й лінгвістика) - інформацію.

Найближчою до науки філософською галуззю є філософія науки, котра виділилась у другій половині XX століття у якості самостійної філософської галузі і часом розглядається дослідниками як «прикладна філософія» [Лебедев 2014: 114-115] або ж як «теорія науки» [Кохановский, Лешкевич, Матяш, Фатхи 2008: 7; Хрусталёв 2009: 146]. 3 цим останнім навряд чи можна згодитись, оскільки предмет філософської рефлексії є суттєво узалежнений від світоглядних настанов філософа, а її висновки найчастіше не можуть бути об'єктивно верифіковані. Набагато більш вірогідними нам здаються погляди тих філософів науки, котрі 
окреслюють цю галузь знань як «аналітичну епістемологію» чи «аналітичну філософію» [Рорти 1997: 127; Никифоров 1998].

Суміжною з мовознавством є ще одна дисципліна - філософія мови. Філософія мови дослідницька галузь філософії, котра з'ясовує роль мови й мовлення в пізнавальних процесах і структурах свідомості. Це один із ключових напрямів дослідження в сучасній аналітичній філософії, що став певним особливим стилем філософського мислення, спрямованого переважно на питання про способи побудови теорій і засади впорядкування мовних засобів вираження знань. Філософи мови визначають онтологічну сутність мови, співвідношення сфери мови й дійсності, мови і людини, мови і суспільства, мови і культури чи мови й етносу. Водночас їх мало цікавлять суто лінгвістичні проблеми, наприклад, чим є мова у стосунку до мовлення, пам'яті чи мислення або чим відрізняється соціолект від ідіолекту. Практично поза сферою зацікавлень філософів мови залишаються й проблеми онтології чи епістемології окремих лінгвальних функцій (слово, речення, текст, дискурс). Усі ці проблеми повинно опрацьовувати саме мовознавство. Але без визначення онтологічної суті цих явищ їхнє лінгвістичне дослідження абсолютно неможливе. Потрібна власне наукова чи метанаукова дисципліна, котра повинна вивчати такі проблеми. Це i $\epsilon$ методологія лінгвістики.

Філософію мови не слід сплутувати не тільки із самим мовознавством чи його методологією, але й з іншими науками, які досліджують мову, наприклад, із психологією мови, яку активно опрацьовували свого часу В. Вундт і Л. С. Виготський чи із соціологією мови, наприклад, у працях Г. Тарда.

Методологію як науку (або метанауку) про побудову людської пізнавальної діяльності виділили в окрему дисципліну приблизно в той самий час, що й філософію науки (у другій половині XX століття). На нашу думку, методологія - це перехідний тип інтелектуальної діяльності, що поєднує суб’єктно-прагматичний характер філософії науки й об'єктноаргументаційний характер науки. Методологія становить сукупність базових настанов щодо розуміння: а) онтології об'єкта пізнання, тобто «вихідні метанаукові презумпції та переконання відносно природи об'єкта» [Голубовська 2012: 69] (у лінгвістиці це настанови щодо питань, чим є мова, мовлення, мовний досвід), б) епістемології його дослідження (як співвідносяться лінгвіст та об'єкт його пізнання, чи і яким чином є можливе наукове пізнання мови, мовлення, мовного досвіду), а також в) методики самого дослідження (якими способами здійснювати лінгвістичні пізнавальні процедури). Подібне розуміння сутності методології знаходимо в працях Е. Г. Юдіна [Юдин 1978] і Н. В. Наливайко [Наливайко 1990]. В. А. Глущенко, зокрема, звертає увагу саме на онтологічну складову методології: «Онтологія виступає в ролі засобу, за допомогою якого дослідник сприймає світ як деяку певним чином розчленовану цілісність, подану йому в системі філософських категорій» 
[Глущенко 2016: 19]. При цьому вчений виділяє ті ж самі три складники методології, називаючи їx відповідно онтологією, телеологією i операціональною складовою: «Трактування лінгвістичного методу як складної логічної одиниці, що включає в себе онтологічний, операціональний і телеологічний компоненти, видається перспективним з погляду вивчення одиниць і категорій усіх мовних рівнів. Запропонований підхід дозволяє об’єднати у цілісній концепції методу такі різнорідні, але взаємопов'язані феномени, як принципи / підходи, операції (прийоми, процедури) та мета дослідження» [там само: с. 20]. Цілковиту рацію має І. О. Голубовська, котра вважає, що методологічний чинник «має виступати провідним при виділенні тієї або тієї «парадигми» [Голубовська 2012: 69].

Особливо велике значення має методологія для тих наук, об'єкт яких не є безпосередньо емпірично даним (не є фізичним, матеріальним предметом). Без сумніву до таких наук належить і мовознавство. Першим науковцем, хто експліцитно й однозначно узалежнив лінгвістичне дослідження від методології, був саме Фердинанд де Соссюр (хоча він ще не вживав такого терміна, а говорив про «точку зору») [див. Просяник 2018а,: 418; Просяник 2018б: 233]. Усі його попередники (Ф. Бопп, В. фон Гумбольдт, А. Шляйхер, Г. Штейнталь чи А. Лескін) різною мірою зосереджувалися на пошуку методів безвідносного пізнання мовного об’єкта, який вони намагалися максимально «визволити» від людини-носія. «Об'єктивне» пізнання мови як історичного духу народу, як культурної психології етносу чи як вродженої психофізіологічної функції організму потребувало опрацювання не лише різних методик аналізу матеріалу й концептуалізації даних, але й цілком відмінних методологічних підстав для такого аналізу та концептуалізації. Саме Соссюр першим зрозумів цю залежність. Він разом з І. О. Бодуеном де Куртене, М. В. Крушевським, О. О. Потебнею (і ще декількома лінгвістами-антропоцентристами) не лише онтологічно концептуалізував мову як психосоціальну функцію людської діяльності, але й окреслив це положення як методологічну базу дослідження. Узалежнення мови / мовлення від досвіду / діяльності людини, а пізнання мовної діяльності - від методологічних настанов мовознавця виразно релятивізувало лінгвістику й змусило наступні покоління мовознавців, з одного боку, усвідомити свою метарефлексивну позицію щодо об'єкта, а з іншого - усвідомити необхідність опрацювання більш гнучких методів дослідження мовного досвіду саме як людської (зокрема й власної) діяльності. Можна погодитися з поширеною тезою, що Ф. де Соссюр був творцем сучасної лінгвістики й «батьком» структуралізму, але лише в одному: без сумніву, мовознавство ХХ століття (і передусім саме структуралізм в усіх його виявах) стало виразно методологічним. Ніколи до Ф. де Соссюра стільки часу й місця в мовознавчих дослідженнях не відводили 3'ясуванню своєї методологічної позиції та методологічним дискусіям 3 опонентами. У цьому сенсі його можна вважати засновником якісно нової парадигми в лінгвістиці. Після Ф. де Соссюра вже не прийнято ігнорувати роль мовознавця в лінгвістичних дослідженнях і 
сприймати об'єкт цієї науки як даний і незалежний від дослідника. Мовознавці та теоретики науки загалом завжди усвідомлювали, що конфлікти й суперечки між представниками різних течій i напрямів у лінгвістиці базуються передусім на відмінності методологічних i філософських (світоглядних) підстав дослідження [Мурзин 1992; Ньюмейер 1996; Мусорин 2000; Ревзина 2004; Манерко 2006]. Проте все частіше лінгвістична методологія стає предметом самостійного вивчення й визнається необхідним елементом кожного мовознавчого дослідження [див. Степанов 1998; Лещак 2002; Лабащук 2012; Мищенко 2015; Заика 2016). Отже науковість мовознавства спирається передусім на його методологічність.

\section{ЛІТЕРАТУРА}

Бірта, Г. О., Бургу, Ю.Г. (2014), Методологія і організація наукових досліджень. Київ, URL: https://pidruchniki.com/1821100160987/dokumentoznavstvo/sutnist_nauki (1.02.2020) [Birta, H. O., Burgu, Ju. H. (2014), Metodolohiya i orhanizaciya naukovikh doslidzhen'. Kiyiv].

Глущенко, В. А. (2016), Ідея мовного розвитку в студіях О. О. Потебні. Вісник Маріупольського держ. ун-ту. Сер.: Філологія. Маріуполь. Вип. 14. 69-75 [Hlushchenko, V. А. (2016), Ideya movnoho rozvitku v studiyakh O. O. Potebni. Visnik Mariupolskoho derzh. un-tu. Ser.: Filolohiya, Mariupol. Vip. 14. 69-75].

Голубовська, I. O. (2012), Проблема методології лінгвістичних досліджень у міждисциплінарному висвітленні, Studia Linguistica. Вип. 6. 67-75 [Holubovs'ka, I. O. (2012), Problema metodolohiyi linhvistichnikh doslidzhen' u mizhdisciplinarnomu visvitlenni. Studia Linguistica. Vip. 6. 67-75].

Заика, В. И. (2016), Методология функционального прагматизма для лингвоанализа художественной речи. Język i metoda 3. Język rosyjski w badaniach lingwistycznych XXI wieku [Zaika, V. I. (2016), Metodolohiya funktsional'noho pragmatizma dla lingvoanaliza khudozhestvennoy rechi. Język $i$ metoda 3. Język rosyjski w badaniach lingwistycznych XXI wieku].

Кохановский, В. П., Лешкевич, Т. Г., Матяш, Т. П., Фатхи, Т. Б. (2008). Основы философии науки, Ростов-на-Дону [Kokhanovskiy, V. P., Leshkevich, T. G., Matyash, T. P., Fatkhi, T. В. (2008). Osnovi filosofii nauki, Rostov-na-Donu].

Лабащук, М. (2012), Динамика структуры вербального знака в онтогенезе (методологический взгляд), Bielsko-Biała [Labaszczuk, M. (2012), Dinamika strukturi verbal'nogo znaka v ontogeneze (metodologicheskiy vzglyad), Bielsko-Biała].

Лебедев, С. А. (2014), Курс лекций по философии науки, Москва [Lebedev, S. А. (2014), Kurs lektsiy po filosofii nauki, Moskva].

Лещак, О. (1996), Языковая деятельность. Основы функциональной методологии лингвистики, Тернополь [Leshchak, O. (1996), Yazikovaya deyatelnost'. Osnovi funktsional'noy metodologii lingvistiki, Ternopol'].

Лещак, О. (2002), Очерки по функциональному прагматизму: методология - онтологія эпистемология, Тернополь-Кельце [Leshchak, O. (2002), Ocherki po funktsional'nomu pragmatizmu: metodologiya - ontologiya - epistemologiya, Ternopol'-Kielce].

Манерко, Л. А. (2006), Наука о языке: парадигмы лингвистического знания. Учебное пособие, Рязань [Manerko, L. A. (2006), Nauka o yazike: paradigmi lingvisticheskogo znaniya. Uchebnoye posobiye, Ryazan'].

Мищенко, О. В. (2015), История и методология языкознания. Екатеринбург [Misshenko, О. V. (2015), Istoriya i metodologiya yazikoznaniya. Ekaterinburg].

Мурзин, Л. Н. (1992), Проблемы и направления современной лингвистики, Пермь [Murzin, L. N. (1992), Problemi i napravleniya sovremennoy lingvistiki. Perm'].

Мусорин, А. Ю. (2000), О философских основах традиционного языковедения. Наука. Университет 2000. Новосибирск. 106-109 [Musorin, А. Ju. (2000), O filosofskikh osnovakh traditsionnogo yazikovedeniya. Наука. Университет 2000. Novosibirsk. 106-109].

Наливайко, Н. В. (1990), Гносеологические и методологические основы научной деятельности, Новосибирск [Nalivayko, N. V. (1990), Gnosiologicheskiye i metodologicheskiye osnovi nauchnoy deyatel'nosti, Novosibirsk]. 
Никифоров, А. Л. (1998), Философия науки: история и методология: уч. пособие,. Москва [Nikiforov, A. L. (1998), Filosofiya nauki: istoriya i metodologiya: uch. posobiye, Moskva].

Ньюмейер, Ф. Дж. (1996), Спор о формализме и функционализме в лингвистике и его разрешение. Вопросы языкознания. № 2. 43-54 [Newmeyer, F. J. (1996), Spor o formalizmie i funktsionalizmie v lingvistike i ego razresheniye. Voprosi yazikoznaniya. No 2. 43-54].

Просяник, О. П. (2018а), Наукова концепція Ф. де Соссюра: досвід реінтерпретації. Дис. ... доктора філол. наук, Київ [Prosyanik, O. P. (2018), Naukova kontseptsiya F. de Saussure'a: dosvid reinterpretatsiyi. Dis. ... doktora filol. nauk, Kiyiv].

Просяник, О. П. (2018б), Фердинанд де Соссюр: деміфологізація концепції: монографія. Харків [Prosyanik, O. P. (2018), Ferdinand de Saussure: demifolohizatsiya kontseptsiyi: monohrafiya, Kharkiv].

Ревзина, О. Г. (2004), Лингвистика XXI века: на путях к целостности теории языка. Критика и семиотика. Вып. 7. 11-20 [Revzina, O. G. (2004), Lingvistika XXI veka: na putyakh k tselostnosti teorii yazika. Kritika i semiotika. Vip. 7. 11-20].

Рорти, Р. (1997), Философия и зеркало природы, Новосибирск [Rorty, R. (1997), Filosofiya i zerkalo prirodi, Novosibirsk].

Степанов, Ю. С. (1998), Язык и метод: К современной философии языка, Москва [Stepanov, Yu. S. (1998), Yazik i metod: K sovremennoy filosofii yazika, Moskva].

Хрусталёв, Ю. М. (2009), Философия науки и медицины: учебник. Москва [Khrustalev, Үu. М. (2009), Filosofiya nauki i meditsini: uchebnik, Moskva].

Юдин, Э. Г. (1978), Системный подход и принцип деятельности. Методологические проблемы современной науки. Москва [Yudin, E. G. (1978), Sistemniy podkhod i printsip deyatel'nosti. Metodologicheskiye problemi sobremennoy nauki, Moskva].

Leszczak, O. (2013), Społeczny i empiryczny charakter transcendentalnego antropocentryzmu Immanuela Kanta: problem istoty człowieczeństwa. Respectus Philologicus. Nr. 24 (29). 21-35.

Mazu,r M. (1981), Zagadnienie prawdy w nauce. Zeszyty Naukowe Stowarzyszenia PAX. Nr 1 (30). 79-92. 